\title{
Dissemination of Gandang Tasa Traditional Music Performance Through Social Media in West Sumatra
}

\author{
Asril $^{1 *}$, Andar Indra Sastra ${ }^{2}$, Adjuoktoza Rovylendes ${ }^{3}$ \\ ISI Padangpanjang, Padangpanjang, West Sumatra, Indonesia \\ *Corresponding Author, Email: asrilmuchtar2017@gmail.com
}

\begin{abstract}
Gandang Tasa is a percussion folk music that developed in rural areas in West Sumatra, such as in Padang Pariaman Regency, Pariaman City, and in Maninjau, Agam Regency, West Sumatra. The most development occurred in Padang Pariaman Regency. The distribution of gandang tasa is done traditionally from one nagari (village) to another through gandang tasa teachers who are in charge to teach. In the present, the spread of gandang tasa shows in various contexts is conducted through social media such as Facebook, blogspot, and YouTube, so that it spreads quickly and extends from its realm of existence. The aim of this research is to discuss the use of social media such as Facebook, blogspot and especially YouTube as the media for the distribution of the gandang tasa show. This study uses a qualitative method. Data is collected through studies on social media and field studies. Data from social media is collected by watching various gandang tasa show through YouTube, Facebook and blogspot. Field studies were conducted to observe the distribution of gandang tasa in communities that still use traditional methods. The results showed that the use of social media of Facebook and especially YouTube became the fastest media to spread the show of gandang tasa until it spreads beyond gandang tasa cultural areas.
\end{abstract}

Keywords: Dissemination, Gandang Tasa, social media, YouTube

\section{INTRODUCTION}

The spread of Gandang Tasa has made use of a great deal of social media services. One of the instruments used in smartphones as mobile phones are capable of recording images in the form of photos and videos. Besides, smartphone cameras are easy to use to record various activities related to Tandang Gandang, from rehearsals to various contexts of the show that can be recorded. The results of the recording, then, are disseminated through social media, such as Facebook, Instagram, Blogspot, and YouTube. However, YouTube has preferably become a popular choice for distributing videos of Tandang Gandang. YouTube, connected to the internet, is easily accessed by anyone anywhere so that various activities related to Gandang Tasa to the various contexts of the show can be watched by many people. The performance of Gandang Tasa via YouTube has spread rapidly, crossing the regional, social and cultural boundaries. Thus, this makes possible various types of activities and performances of Gandang Tasa in the virtual world to be presented before the appreciators and spectators.

This had been inversely proportional to the situation when Gandang Tasa had not used social media services for its distribution. In the past, the spreading of Gandang Tasa was done through live performances in a variety of ritual, ceremonial, and entertainment contexts which were appreciated directly by the audiences and people who had an interest in it. Dissemination also takes place through stories from individuals, groups of people, and Tandang Gandang teachers who are intentionally brought it into the teachings of Gandang Tasa in various villages. Such distribution is, therefore, very slow, so that it tends to develop only in certain areas, for example in Pariaman and Maninjau and by the nomads of the two regions in their overseas areas. While those coming from other areas in West Sumatra that do not have the tradition of Gandang Tasa and are barely touched by its dynamic expansion. Bringing both the aforementioned situations of the spreading of Gandang Tasa, the current paper aims to discuss the role of social media in the dissemination of Gandang Tasa that can break up regional, social, and cultural barriers, as well as its slothful diffusion when the old fashioned method was applied.

\section{LITERATURE REVIEW}

Several previous studies discussed the role of Gandang Tasa in the context of Tabuik rituals and other contexts from various perspectives including that of the show $[2,3,4,8]$. The authors who have done so include Asril, Sastra, \& Rovylendes writing the article "Performativity of Gandang Tasa in the Mauluik Ritual in Sicincin, Pariaman, West Sumatra" [3]. This article discusses the role of Gandang Tasa in building a joyful and aggressive atmosphere as a major part of the Mauluik ritual procession in Sicincin, one of the nagari (village) in Padang Pariaman Regency. Gandang Tasa performativity, as proposed in the study, is manifested through the expression, behavior, appreciation of 
Gandang Tasa players who are able to change the mood from happiness, fierce to trance (unconsciousness).

Later, the second paper "What is it: An Event to Renew Social Bonds Through the Performativity of Gandang Tasa in the West Sumatra Pariaman Community." discusses Gandang Tasa from various villages in Padang Pariaman Regency and Pariaman Municipality [4]. As stated, the event is performed alternately by some groups from one village to another [4]. The Gandang Tasa performance at the event of Manapa aims to foster friendship among its players, share their experiences, and encourage teenagers to learn how to be good players [4].

The article, "The Role of Gandang Tasa in Building Spirit and Atmosphere in the Tabuik Show in Pariaman" [2], discusses the role of Gandang Tasa in various Tabuik rites. Asril grouped the atmosphere based on the atmosphere in the Tabuik rites, whether it involves sadness, emotion, joy, solemnity, fierce or hard dimensions such as fights between supporters of Tabuik. The very important role of the Gandang Tasa is to build an atmosphere and emotions of anger, ferociousness, and the aggressive atmosphere to trigger a fight and ether of joy.

On another occasion, Rikarno wrote an article entitled, "Utilizing an Android Mobile as a Media for Producing Art Learning Tutorial Videos" to discuss how the Android smartphones are used as a learning media for various types of traditional (regional) arts aided in the form of video tutorials so that they are easily taught to students [8]. He observed that traditional arts used as learning materials in schools are very challenging to teach possibly because of media limitations and teachers' low mastery of traditional arts [8]. He adds the use of traditional art tutorial videos through Android mobile phones is very appropriate and very helpful for teachers in teaching students the works of arts.

From the above research papers, the researchers see that no studies comprehensively discuss the spread of Gandang Tasa, specifically when it employs various social media as its disseminating method.

\section{RESEARCH MethoD}

This is a qualitative study whose data are collected through field studies and social media. Data on social media were collected by watching various Gandang Tasa performances via YouTube, Facebook and BlogSpot, while the field study was conducted by observing the distribution of Gandang Tasa in the community that still uses a lot of traditional methods, conducting interviews with Gandang Tasa players, and documenting live performances. Data collection through social media was focused on YouTube to look at the distribution of Gandang Tasa as it is widely used by people and most quickly used as a media to widely spread Gandang Tasa performances in the community outside Gandang Tasa cultural areas.

\section{RESULTS AND DISCUSSION}

Social media in general covers internet-based social interaction practiced virtually by virtual communities. this can be centralized on Facebook, Instagram, and YouTube.
Hermawan in his article stated that "YouTube is a website that facilitates users to share videos they have or limited to enjoying various video clips uploaded by various parties. Various types of videos can be uploaded to this site, such as music video clips from certain musicians, short films, television films, movie trailers, educational videos, video blogs owned by vloggers, video tutorials for various activities, and many more [9].

Hermawan's statement above essentially means a variety of activities uploaded via YouTube which is certainly useful, including the activities related to Gandang Tasa. Gandang Tasa performances, found in social media, such as Facebook, Instagram, and especially YouTube, are mostly uploaded by people who have an interest in Gandang Tasa, its players, and performing arts business owners, including art studio owners. Activities related to Gandang Tasa, especially its live performances, are deliberately carried out for certain purposes. For observers, uploading Gandang Tasa videos is done as an effort to spread it so that people can watch and enjoy them easily and quickly. As for the owners of commercial art studios, their goal is to promote the works of art they are working on. The recorded shows that they upload are not just works of art or songs to play but these can also be the documentation of their performances related to various ceremonial contexts, such as parading brides.

For this, the studio owners usually upload a short video of the show that they record with a smartphone while adding a description of the event or the context of the show. Some also promote their services, like an advertisement telling that they are ready for orders for parading the brides. As added, their tariffs are negotiable, depending on the package chosen by the clients. For example, packages provided are solely parading the brides, parading the bride plus Gandang Tasa performance at the party, or those coupled with the Talempong musical creation in the form of Talempong music combined with a combo band.

Bride parading in Padang Pariaman Regency has been a tradition of a series of marriage ceremonies. This tradition is very common with the accompaniment of the ensemble music of Gandang Tasa and Katumbak - mixed syncretic music from Malay, Minang, and Indian [1], but the most often performed are those with Gandang Tasa. There are two kinds of Gandang Tasa groups, namely the traditional troupes and those from the art studios. When using the Gandang Tasa traditional groups, the performance material is usually a traditional song that is focused on the part of the song called Matam, the song presenting the tingkahan of drums (drum attraction) with Tasa (traditional drums). They rarely wear special clothes for the show and only dress in daily fashion in which neatness is an important element. Meanwhile, Gandang Tasa groups from art studios generally do not perform traditional songs, but they compose their own songs sourced from traditional material and their development. They may add other instruments such as Sarunai and Talempong so that their music is livelier. They wear a bright-colored costume and, visually, they consider the aesthetic element to balance the wedding attire as the accompanists wear nice-looking outfits with designs, patterns, and models of Minangkabau traditional clothing. 
The Gandang Tasa groups that come from art studios, are found concerned in uploading their videos on social media so that their studios can be more widely known by the public The more widespread the distribution of their shows, the more opportunities can get to be invited for the job. They also assume that uploading videos through social media like YouTube and Facebook is easy and cheap. Thus, artists from the art studios do the distribution of Gandang Tasa that have been modified for the consumption of entertainment, while the traditional troupes whose players are mostly traditional artists are usually less skilled or active in using their cameras to upload their performances to social media so that the spread of Gandang Tasa by their groups is relatively slower. They only rely on mouth-by-mouth promotion based on the impressions of the connoisseurs and users of their services.

As for the uploading of the Gandang Tasa performances through social media outside the context of performances for commercial services, the bride parading groups are also widely carried out by Gandang Tasa groups. Their purposes can be divided into two, first to promote their groups and second to expand the distribution of Gandang Tasa as an appreciation for anyone who is interested in it. The first purpose can be understood as an effort to be promoted to the shows held by government agencies, festival organizers, and those who want to study with them. While in the second goal, they seek to expand the spread of Gandang Tasa can be seen as a noble work. They give a sincere appreciation for anyone who wants to learn Gandang Tasa without having to learn directly with them. The videos that they make and upload to YouTube are very good and some are even made in series (episodes) so people who want to learn seriously through videos on YouTube can be good at playing as they show.

The spread of Gandang Tasa through social media is recognized to be very fast and widespread. People from Pariaman and Maninjau residing outside West Sumatra, such as in Pekanbaru, Lampung, Bengkulu, Medan and other big cities and towns in Sumatra to Java can enjoy it without much effort. This condition is inversely proportional to the past when the only service available for learning Gandang Tasa was teachers who were intentionally brought in from Pariaman and Maninjau. However, it is also recognized that learning directly with the teacher and learning through YouTube have different results. Students who learn directly from the teacher can feel and see how the techniques and abilities of a teacher are clearly visible to them, so the reference material used by the teacher is also certain. This can build up a good emotional connection between teacher and student, and lead to an appreciation for the teacher. As acknowledged by the Gandang Tasa teachers, for example, Ajo Kaman from Limau Purut, Padang Pariaman Regency who teaches Gandang Tasa to the Persatuan Keluarga Daerah Pariaman (PKDP) or the Pariaman Regional Family Community in Pekanbaru, there was a shared emotional bond between him and his students (Ajo Kaman, interview on April 28, 2018). Likewise with Ajo M. Nasir from Cubadak Air, Pariaman, who has taught the Gandang Tasa in Bengkulu since fifteen years ago (Ajo Nasir, interview July 28, 2019). Therefore, learning with a teacher is a process experienced directly by Gandang Tasa students that bound them with the teacher emotionally.
Meanwhile, learning via YouTube does not provide the students with the true experience of learning and produces no emotional connection with the teacher appearing in the videos. The virtual world is a pseudo-visible but not palpable reality. As said by Piliang, virtual reality is something that is not real, in the sense that it is not constructed by the structure of matter, body, and particles, but actual, in the sense of being captured by the senses. p.19 [7]. Gandang Tasa performances, exercises, and other activities carried out with Gandang Tasa can only be seen and heard. Interaction with the teacher is not as possible as that in the real world. In this case, there is a tendency for them to form virtual communities that can interact and come together in virtual space based on virtual shared ties p.11 [7]; p.437 [6] because they might reside very far from one another.

Now it must be acknowledged that the era of information technology and the fourth industrial revolution has made easy many people do various jobs and complete any goals. As stated by Leslie, technology not only determines the direction of cultural development but also determines basic human needs in these changes p.474 [5]. Technology determination assumes that technological innovation is the driving force behind social change through the coercion of the logic of social actors. As also emphasized by Liliweri, the next technology is combined with certain fields, such as virtual technology. Thus, essentially, technology refers to the high technology available for humans in any field p.477 [5].

YouTube as a cultural product in the era of Industry 4.0 has been used as media for spreading various activities and events of performing arts. Starting from the training process, performances, to study guides are all uploaded to YouTube so that many people can take advantage of this technology. The Pariaman and Maninjau nomads use this media to be a reference in the creativity of Gandang Tasa. Those who already have the basics of playing Gandang Tasa are more likely to use social media services to learn it. Learning through social media is more efficient in terms of time and cost, rather than bringing in teachers from their hometown. Their way of thinking is also different from their groups who learn Gandang Tasa in their hometown. If they can play Gandang Tasa well, it is not the same as traditional songs that are preserved in their hometown or considered not mastering tradition, for them, it is not a worrying problem, because they do not have a mission to preserve Gandang Tasa. For them, the most important thing is that playing Gandang Tasa is a form of actualization of community and cultural identity through the representation of their performances.

\section{Gandang Tasa Performance Style in FESTIVALS}

At present, there are two styles of the Gandang Tasa festivals in West Sumatra, namely the Pariaman style called Bapereih (a prize competition) and the Maninjau style called the festival. The former style is very strict according to the tradition they practice, where the contestants who have to perform a "mandatory" song that is generally widely known or they can play their own songs that have common characteristics and criteria in Bapereih. The contestants are 
faced with various rules of the game, so they play very carefully, even tend to be stiff, not expressive so they seem afraid of being mistaken rather than playing it freely though they are generally very skilled and have been recognized as great players. The Bapereih festival system has become 'exclusive' among traditional Gandang Tasa artists and enthusiasts only.

However, the Gandang Tasa performances in the Bapereih event held in different places and times turned out to be uploaded to YouTube, especially by the Gandang Tasa groups that were considered the best in each event. Videos uploaded in the 2017-2018 period have been watched thousands of times. Such upload aims for people to enjoy and compare the videos with other groups' performances. This thousands of video watching indicates that there is good and fast dissemination of the Gandang Tasa show via YouTube. Figure 1 below depicts a Gandang Tasa performance at a Bapereih event.

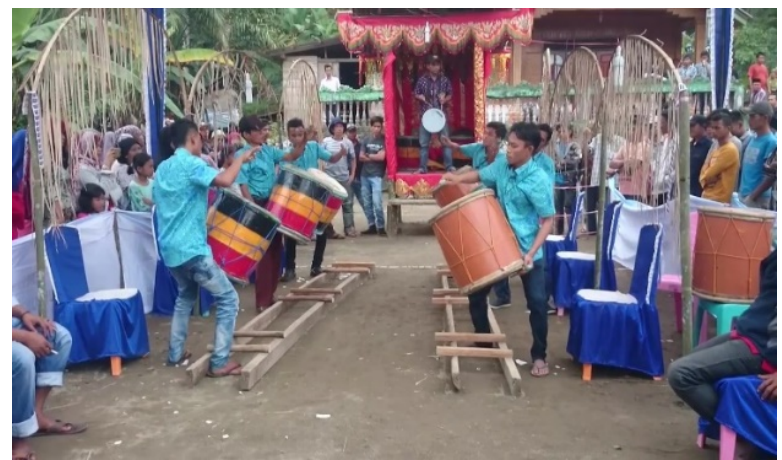

Fig. 1. Pauah Manih performance from Padang Sagopada at a Bapereih event in Pariaman (accessed September 15, 2019)

The following are examples of Gandang Tasa groups in the context of Bapereih which were uploaded to YouTube in the period of 2017-2018.

\begin{tabular}{|c|l|l|l|l|}
\hline No. & $\begin{array}{l}\text { Group Name/ } \\
\text { Festival venue }\end{array}$ & $\begin{array}{l}\text { Uploading } \\
\text { Account }\end{array}$ & $\begin{array}{l}\text { Upload } \\
\text { Date }\end{array}$ & $\begin{array}{l}\text { Watc } \\
\text { h }\end{array}$ \\
\hline 1. & $\begin{array}{l}\text { Gandang Tasa } \\
\text { Palak Juha, } \\
\text { Barangan }\end{array}$ & $\begin{array}{l}\text { Adis } \\
\text { Suhendra }\end{array}$ & $\begin{array}{l}\text { April 26, } \\
2018\end{array}$ & 2,709 \\
\hline 2. & $\begin{array}{l}\text { Gandang Tasa } \\
\text { Pauah Manih } \\
\text { Kp. Tangah, } \\
\text { Pd. Sago }\end{array}$ & $\begin{array}{l}\text { Syahril } \\
\text { Tanjung }\end{array}$ & $\begin{array}{l}\text { Jan 26, } \\
2018\end{array}$ & 5,451 \\
\hline 3. & $\begin{array}{l}\text { Gandang Tasa } \\
\text { Koto Tinggi }\end{array}$ & $\begin{array}{l}\text { Muhammad } \\
\text { Amin }\end{array}$ & $\begin{array}{l}\text { April 25, } \\
2018\end{array}$ & 6,029 \\
\hline 4. & $\begin{array}{l}\text { Sungai } \\
\text { Kamuning, } \\
\text { Manggopoh } \\
\text { Ulakan }\end{array}$ & $\begin{array}{l}\text { Rezy } \\
\text { Fortuna }\end{array}$ & $\begin{array}{l}\text { March } \\
26, \\
2017\end{array}$ & 10,84 \\
\hline 5 & $\begin{array}{l}\text { Gandang Tasa } \\
\text { Tungka Lubuk } \\
\text { Aro }\end{array}$ & $\begin{array}{l}\text { Rizky } \\
\text { Anzafort }\end{array}$ & $\begin{array}{l}\text { Oct 27, } \\
2017\end{array}$ & 4,623 \\
\hline 6. & $\begin{array}{l}\text { Gandang Tasa } \\
\text { Aia Tajun }\end{array}$ & $\begin{array}{l}\text { Nagari Aia } \\
\text { Tajun }\end{array}$ & $\begin{array}{l}\text { April 3, } \\
2018\end{array}$ & 3,557 \\
\hline
\end{tabular}

\section{Table 1. Gandang Tasa Groups in Baperih Festivals}

It is apparent from the above table that Gandang Tasa performances uploaded to YouTube from 2017 to 2018 have been watched thousands of times.

The style of the Gandang Tasa festivals conducted by the Gandang Tasa Maninjau artists is very interesting, creative, and inspiring. Participants make their own creations of the songs featured in the festivals. They are not required to play some sort of compulsory songs and this stimulates creativity for each group appearing in the festival. The composition of their songs and rhythm motifs is very creative and varied as composed of several parts. To support the show to be more interesting, the groups create their own well-arranged and artistic 'choreography' in which simultaneous and wellordered movements are arranged based on fragments of phrases and periods of Gandang Tasa song rhythms so that overall they look harmonious.

The recorded performances from Gandang Tasa groups with various compositions or songs and choreography creations are often displayed on social media, and YouTube is the most chosen one. The performance of Gandang Tasa groups that exposed on YouTube spread rapidly to various other groups and the wider community. The distribution of the Gandang Tasa performances through social media was much appreciated by those living outside the Gandang Tasa cultural area. For example, the Pariaman and Maninjau people inside and outside West Sumatra. One of the Manantau areas that develop the Gandang Tasa performance style obtained through social media is fostered by a trainer and develops as the group of Sungai Rumbai, Darmasraya. This shows that the results of learning through YouTube have been cultivated. On one occasion the authors had been one of the judges of the Gandang Tasa festivals held at Sungai Rumbai in March 2019 and had watched closely the material of their performances which is very creative and varied, and diverges from group to group as seen Figure 2 and 3 below.

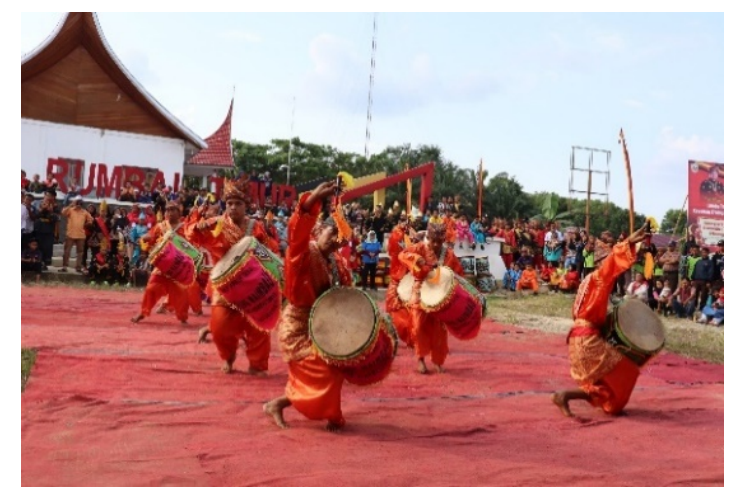

Fig. 2. Gandang Tasa Performance 


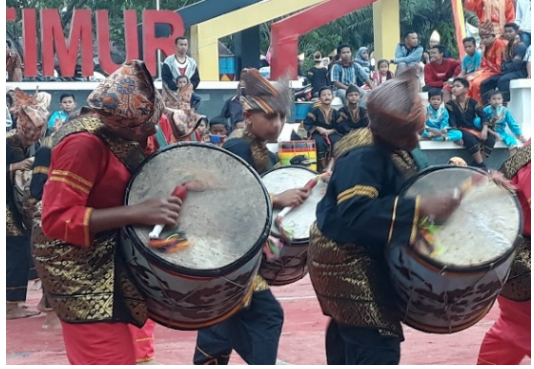

Fig. 3. Gandang Tasa Performance at the festival held in Sungai Rumbai, Darmasraya, West Sumatra, Indonesia in March 2019 with different visually and aesthetically fascinating styles and costumes (Photo: Asril Muchtar)

While there are many groups that are not involved in the Bapereih festival, they develop their own form and style of performance. For example, the groups owned by 'professional' art studios providing services for commercial purposes prioritizes the beauty of the visual aspects of the show. They arrange their own motifs and rhythm patterns from traditional materials and the results of their development. They also pay special attention to the prominence of the atmosphere with a joyful expression supported by bright-colored clothing. The visual aspect of the show has become the aesthetic aspect of their performances. These creations were inspired by watching the recorded performances from various groups through social media, especially YouTube. Then the results of their creations and performances are uploaded back to YouTube, Facebook, and Instagram so that there will be a rapid spread across the borders of the cultural areas quickly. One example is the Binuang Sati Studio in Lubuk Alung directed by Aditya Nugraha.

In addition, there are also some performances that are made in the context of the Tabuik and entertainment uploaded to YouTube that gets the attention from their spectators as seen in Figure 4 and 5 below.

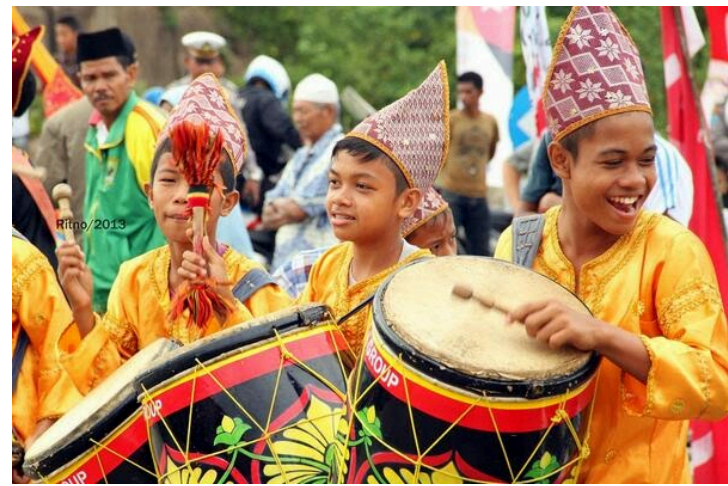

Fig. 4. A children's group performing the Gandang Tasa at the annual Tabuik show in Pariaman (accessed September 15, 2019)

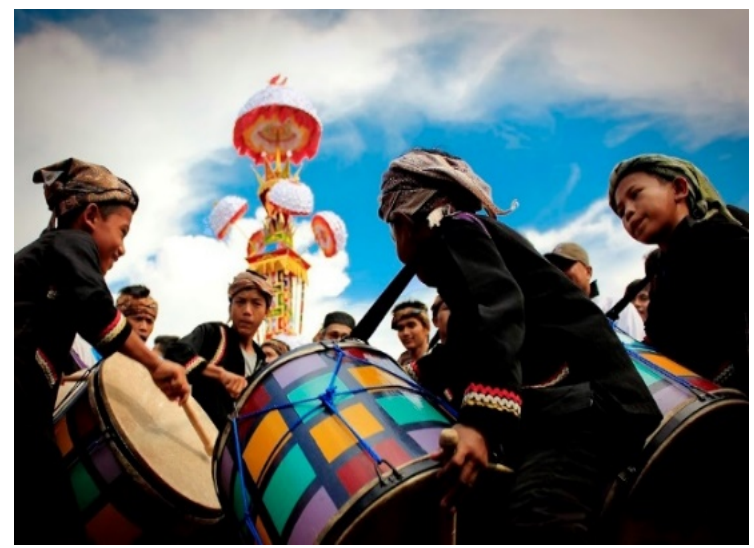

Fig. 5. Children's' expression whilst performing Gandang Tasa

\section{Conclusion}

Gandang Tasa performances uploaded through social media and especially YouTube have promoted a very rapid and widespread blowout beyond the boundaries of the original area and its development in Pariaman and Maninjau as its social and cultural barriers. Dissemination through social media has accelerated the development of Gandang Tasa by the Pariaman and Maninjau nomads who can learn it via YouTube effortlessly and without spending money and special time, when compared to learning through teachers brought from their hometowns. For entertainment businesses such as art studios, YouTube is used as a cheap promotional media to introduce their studios more broadly to the public. However, those learning it from the virtual reality do not experience the emotional connection between teacher and student as do they in the real world.

\section{REFERENCES}

[1] Asril. "Katumbak Musik Sinkretik Minangkabau yang Makin Memudar [Katumbak, Minangkabau Syncretic Music that Is Increasingly Fading]" dalam Jurnal Aswara, jilid 3 Bil. I. Kuala Lumpur: Akademi Seni Budaya dan Warisan Kebangsaan (2008).

[2] Asril, Asril. "Peran Gandang Tasa Dalam Membangun Semangat Dan Suasana Pada Pertunjukan Tabuik Di Pariaman [The Role of Gandang Tasa in Building the Spirit and Atmosphere in Tabuik Performance in Pariaman]." Jurnal Humaniora 27.1 (2015): 67-80. DOI: https://doi.org/10.22146/jh.6411

[3] Asril, Andar Indra Sastra, dan Adjuoktoza. "Performativity of Gandang Tasa in the Mauluik Ritual in Sicincin, Pariaman, West Sumatra," Arts and Design Studies Journal, Vol. 67, 2018, p.15-23. DOI: https://doi.org/10.7176/ADS

[4] Asril, Asril, Andar Indra Sastra, and Adjuoktoza Rovylendes. "Manapa: An Event to Renew Social 
Bonds through the Performativity of Gandang Tasa in the Pariaman Community West Sumatera." Seventh International Conference on Languages and Arts (ICLA 2018). Atlantis Press, 2019. DOI: https://doi.org/10.2991/icla-18.2019.6

[5] Liliweri, Alo. Pengantar studi kebudayaan [Introduction to Cultural Studies]. Nusa Media, 2014.

[6] Piliang, Yasraf Amir. Dunia yang dilipat: Tamasya melampaui batas-batas kebudayaan [The Folded World: Touring Beyond Cultural Limits]. Matahari, 2011.

[7] Piliang, Yasraf Amir. Dunia Yang Berlari: Dromologi, Implosi, Fantasmagoria [The Racing World: Dromology, implotion, phantasmagoria]. Sleman: Aurora, 2017.

[8] Rikarno, Riki. "Pemanfaatan Handphone Android sebagai Media Produksi Video Tutorial Pembelajaran Seni [Utilizing Android Handphone as a Medium for Producing Art Learning Videos]." Melayu Arts and Performance Journal 1.1 (2019): 73-87. URL: http://journal.isipadangpanjang.ac.id/index.php/MAPJ/article/view/63 2

[9] Hermawan. "Pengertian Youtube Beserta Manfaat dan Fitur-fitur Youtube yang Perlu Anda Ketahui [Things You Need to Know About Youtube: Its Features and Benefits].", Nesabamedia, 15-9-2019, https://www.nesabamedia.com/pengertian-youtube/. 